\title{
Review
}

\section{Bats as bushmeat: a global review}

\author{
Simon Mickleburgh, KeRRY WAylen and Paul RaCey
}

\begin{abstract}
A questionnaire survey and literature review revealed the extent of hunting of bats for bushmeat in the Old World tropics. High levels of offtake were reported throughout Asia, the Pacific islands and some Western Indian Ocean islands, where fruit bats of the genus Pteropus are eaten extensively. Most hunting in Africa was reported in western states and the largest fruit bat Eidolon helvum was preferred. Insectivorous bats are also eaten, particularly Tadarida in Asia. Hunting is both for local consumption and commercial, sometimes involving crossborder transactions. The high levels of hunting reported and the low reproductive rate of bats indicate there are likely to be severe negative effects on bat populations, and declines of several species are documented. Although there has been only one reported attempt to manage offtake, this indicates that it is possible and apparently successful. Furthermore, voluntary controls on hunting have halted declines in bat numbers. There have been several initiatives to reduce hunting pressure and conserve threatened bat species, mainly on islands that, when sustained, have been successful. More education projects and community-based conservation initiatives should be encouraged together with further attempts at sustainable harvesting in situations where disease risk has been evaluated.
\end{abstract}

Keywords Bats, bushmeat, commercial hunting, Eidolon, Pteropus, sustainability, Tadarida.

This paper contains supplementary material that can be found online at http://journals.cambridge.org

\section{Introduction}

There is growing concern about the potential impact 1 of the bushmeat trade on a range of animal species (Robinson \& Bennett, 2000). Attention has often focused on primates and other large mammals (Bowen-Jones \& Pendry, 1999) and to date there has been little information

Simon Mickleburgh ${ }^{*}$ and Kerry $\mathrm{WAyleN}^{\dagger}$ Fauna \& Flora International, Cambridge, UK.

PAul RaCeY (Corresponding author) School of Biological Sciences, University of Aberdeen, Aberdeen, AB24 2TZ, UK. E-mail p.racey@abdn.ac.uk

${ }^{\star}$ Current address: The Rufford Maurice Laing Foundation, London, UK.

${ }^{\dagger}$ Current addresses: Centre for Environmental Policy and Division of Biology, Imperial College London, Silwood Park Campus, Ascot, UK, and Macaulay Institute, Aberdeen, UK.

Received 5 June 2008. Revision requested 12 August 2008.

Accepted 12 December 2008. on bats. There is some evidence that hunting and trade is having a significant impact on bat populations in the Pacific islands and South-East Asia (Mickleburgh et al., 2002) and also in Madagascar (Jenkins \& Racey, 2008) but there is no overall view of its potential global impact on bats. Furthermore, recent reviews of emergent viral diseases in bats have raised concerns that eating bats as bushmeat may transmit such diseases (Messenger et al., 2003).

The low reproductive rate of bats makes them especially vulnerable to harvesting for bushmeat. In several life-history characteristics bats are similar to primates that are severely impacted by the bushmeat trade (Bowen-Jones \& Pendry, 1999). Bats are long-lived and often roost communally, which increases their visibility and susceptibility to hunters. Their vulnerability may be further increased by roost location and fidelity. Roosts, such as caves and trees, are vulnerable to disturbance and bats return seasonally to roost sites, making them predictable targets. Many bat species also face other threats, such as habitat loss, throughout their range, and these threats may interact with hunting to increase their vulnerability further. The global status of bats is reviewed by Mickleburgh et al. (1992; for Old World fruit bats) and Hutson et al. (2001; for all other bats).

Over $20 \%$ of all mammal species are bats (Simmons, 2005). On some islands bats may be the only native mammals and may be keystone species in ecosystems (Cox et al., 1992) as pollinators and seed dispersers of plants, many of which are economically important (Fujita \& Tuttle, 1991). The hunting of bats for bushmeat could therefore be a significant threat to their populations, and it is of crucial conservation and economic importance to discover the extent of hunting. We present here the results of a global survey of the use of bats as bushmeat, discuss the potential conservation problems this causes, and make recommendations on how these problems could be tackled.

\section{Methods}

This study was initiated over April-September 2004 using two principal methods. The first approach was a literature review. This included literature accumulated by a Fauna $\&$ Flora International review of the bushmeat trade (BowenJones et al., 2002) together with online publications and media reports. Most material reviewed was in English; some was in Spanish and French. The second approach involved a questionnaire (Appendix 1) widely distributed by e-mail and advertised in the journal Phelsuma and in African Bat Conservation News. The questionnaire requested information 
about traditional and current use of bats as bushmeat, the impact on bat populations, the techniques used to hunt bats and the relative importance of bats in local bushmeat trade. Where relevant, the basis of the information provided was also queried: for example, the suggestion that hunting adversely affected bat populations was only occasionally supported by research. Where necessary, data from questionnaires were clarified and supplemented by further enquiries. Anecdotes and other information from respondents were also noted.

\section{Results}

\section{Literature review}

The literature review revealed 119 references with some information indicating bat consumption, including 87 journal papers, seven media reports, three web articles, four university theses or other manuscripts, nine government reports and $20 \mathrm{NGO}$ reports. Given the volume of literature on bushmeat, bat consumption is not a prominent topic. Thirty-one apparently comprehensive studies of bushmeat hunting or trade did not mention bats. Whilst additional reports may exist, especially in languages other than English, the references reviewed are likely to give a representative indication of the level of use of bats as bushmeat. Information provided by respondents about the use of bats in traditional medicine will appear elsewhere. The terms fruit bat and flying fox are used interchangeably for members of the Pteropodidae.

\section{Questionnaire}

A total of 109 individuals responded to the request for information, with 90 completing questionnaires (Appendix 2). The respondents provided 138 reports on bat consumption (Table 1) and the geographical distribution of these is given in Table 2. The methods used to hunt bats are listed in Table 3 . The information below only covers areas where significant bat consumption has been reported (Table 2). Other areas, such as Eurasia, North Africa, the Arabian Peninsula, Australia, New Zealand, North and Central America and the Caribbean are excluded because there was little or no evidence of consumption of bats.

\section{The use of bats as bushmeat}

Generalizations concerning each area surveyed are presented in Table 1. Specific details are given below, by region.

\section{South-East Asia}

Cambodia Hunting has impacted bat populations, particularly Tadarida plicata.
Indonesia Bergmans \& Rozendaal (1988) noted $>100$ Pteropus alecto for sale by one trader in a market in Sulawesi in 1982 and several other species were also regularly traded. Clayton \& Milner-Gulland (2000) made detailed observations of the meats, including bat meat, in markets in north Sulawesi; in the early 1990s a single fruit bat was worth USD $0.23-1.14$, and 25-50 bats per week were typically sold; this reached 300 in 1997. In each of two markets in Ujung Pandang, Sulawesi, 100-200 flying foxes were traded daily and c. $8 \%$ of bats from Ujang Pandang were exported to supermarkets in Manado City (Heinrichs, 2004). In Jakarta Pteropus vampyrus were offered by at least two market vendors for USD 10 each, who each sold c. five per week (Fujita \& Tuttle, 1991). Bats were also readily available at Manadonese restaurants (Fujita, 1988). However, on Karakelang, most bats were eaten by the trappers and hunting was not commercially driven (Riley, 1998). Whole roosts could be devastated by harvesting for markets in north Sulawesi (Clayton \& Milner-Gulland, 2000) and five species, including one endemic, were threatened by hunting on the islands of Sangihe and Talaud, with Acerodon celebensis possibly warranting threatened status (Riley, 2002). Fruit bats were heavily hunted on Karakelang Island (Riley, 1998). Market surveys and colony observations indicated that c. 30,00o bats were killed per year in southern Sulawesi, and overharvesting seriously threatens flying fox populations (Heinrichs, 2004). Populations of A. celebensis and Pteropus griseus mimus may have been decimated and $P$. alecto populations reduced by $25 \%$ (Heinrichs, 2004). In some regions smaller bat species were hunted because flying foxes were no longer present (Heinrichs, 2004). The impact of hunting in Indonesia may be exacerbated because hunters leave obstructions in place that are used to catch cave bats, which then preclude reestablishment of some colonies. In Kalimantan c. 4,500 Pteropus vampyrus natunae were taken from one location over a month, resulting in severe population decline (Streubig et al., 2007). The bats were sold in markets for USD 0.63-2.20 each. There has been some response to problems in this region. Bat Conservation International and Fauna \& Flora International supported the work of Scott Heinrichs to educate people in Sulawesi about the role that bats, particularly flying foxes, play in the ecosystem, and their conservation status, and he liaised with local academics, students, restaurateurs and villagers.

Lao PDR The only confirmed large colony of the wrinklelipped bat Tadarida plicata is heavily exploited, with several thousand bats per day being sold in the market of LouangNamtha. Tadarida teniotis were also sold in markets at Ban Lak (Francis et al., 1999) and bats may have been exported to Thai markets (Robinson, 1994). In the Nam Ha protected area trade was primarily local, with $97 \%$ of reported sales being to people from the same province and $35 \%$ to people 
TABLE 1 Summary of the use of bats as bushmeat by region and country, with information on levels of consumption, extent of trade, taxa targeted, hunting methods used, any legal controls on hunting, references, and overall summary.

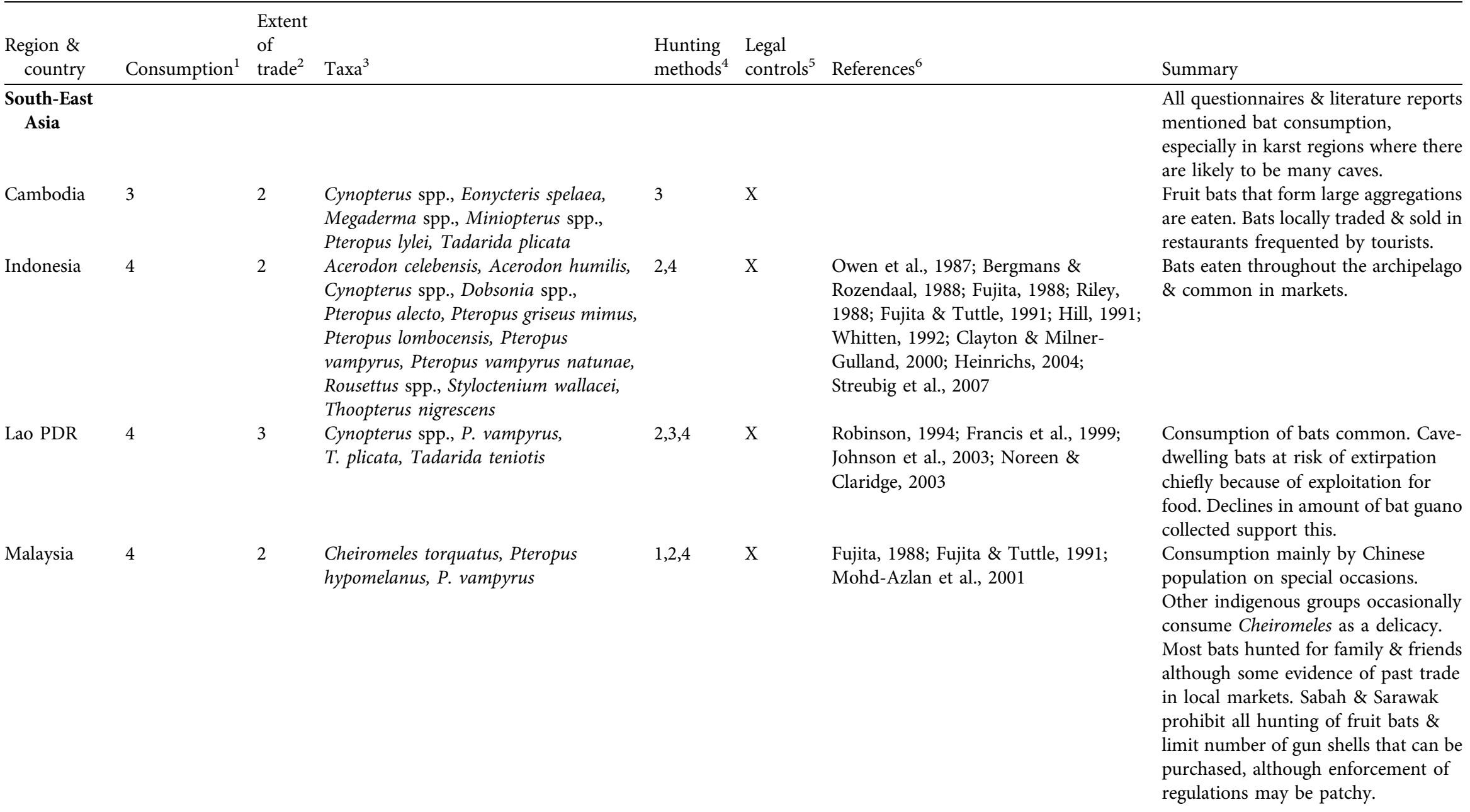


Table 1 (Continued)

\begin{tabular}{|c|c|c|c|c|c|c|}
\hline $\begin{array}{l}\text { Region \& } \\
\text { country }\end{array}$ & Consumption $^{1}$ & $\begin{array}{l}\text { Extent } \\
\text { of } \\
\text { trade }^{2}\end{array}$ & $\operatorname{Taxa}^{3}$ & $\begin{array}{l}\text { Hunting } \\
\text { methods }\end{array}$ & $\begin{array}{l}\text { Legal } \\
\text { controls }^{5}\end{array}$ & References $^{6}$ \\
\hline Myanmar & 3 & 2 & $\begin{array}{l}\text { Craseonycteris thonglongyai, } \\
\text { Rhinolophus marshalli, T. plicata }\end{array}$ & 2 & $\mathrm{X}$ & Bates, 2003 \\
\hline
\end{tabular}

New Guinea

(Papua

New

Guinea

\& Irian

Jaya)

Philippines
2

Aproteles bulmerae, Dobsonia magna,

Dobsonia moluccensis, Miniopterus

schreibersii, Miniopterus magnater,

Miniopterus pusillus, Nyctimene aello,

Nyctimene cyclotis, P. hypomelanus,

Pteropus neohibernicus, Rousettus

amplexicaudatus, Syconycteris australis

2 Acerodon jubatus, Acerodon leucotis,

Cynopterus brachyotis, Dobsonia

chapmani, E. spelaea, Harpyionycteris whiteheadi, Macroglossus minimus,

Nyctimene rabori, Ptenochirus jagori,

P. hypomelanus, Pteropus pumilus,

$P$. vampyrus, $R$. amplexicaudatus,

insectivorous bats
Summary

All species hunted although smaller bats preferred because bones can be eaten with the meat. Bat populations probably not threatened by hunting although impacts vary with village attitudes. Larger cave roosts protected from overharvesting by local communities to ensure supply of guano.

Bats eaten throughout the highlands $\&$ at least some populations adversely affected by hunting. All major caves in Irian Jaya showed signs of disturbance from hunting.

Bats popular on special occasions but not as subsistence food. However, bats often the most popular bushmeat,

partly because other wild meats have become scarce $\&$ bats are easily

hunted. When hunting is at its most intense, in the fruiting seasons, bats are targeted almost every night \& some hunters may take hundreds at a time. Several bat populations, especially tree-roosting or cave-

dwelling species, have been adversely affected by hunting. Because loss of habitat has been a major threat to bat populations hunting now has a proportionately greater impact on those remaining. Cave-dwelling species in Negros have declined dramatically, almost certainly because of the effects of hunting. 
Thailand

4

R. amplexicaudatus, Rousettus

leschenaultii, T. plicata,Taphozous

melanopogon

Vietnam

Cynopterus spp., E. spelaea, Pteropus

spp., Miniopterus spp., T. plicata

East \&

South-East

Asia

Bangladesh 2

China $\begin{array}{lll}\text { Pteropus giganteus } & \mathrm{X} & \mathrm{X} \\ \text { Cynopterus sphinx, Hipposideros } & 1,2,4 & 3\end{array}$

pomona, $P$. giganteus, $R$. leschenaultii,

Rhinolophus spp.
India

(Andaman

\& Nicobar

Islands)

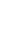

India

(Mainland)

Stebbings, 1987; Lekagul \& McNeely, Bat consumption widely reported \& 1988; Robinson, 1993, 1994, 1995, 1998; cave-dwelling species especially

Magnus, 2001 threatened by hunting.

Thong, 2004

Only immigrant minorities, such as Thais, consume bats, \& only on special occasions. Some populations probably threatened by hunting. In the south fruit bat populations have declined, probably because of hunting, habitat loss \& cave destruction. Heavy hunting pressure reported, especially on Pteropus.

Eaten occasionally by tribal people. Bat consumption reported, especially in the southern provinces of

Guangdong, Guangxi, Sichuan \&

Hainan \& in the south-west. Hunting for bushmeat likely to be detrimental to some populations but entire colonies of fruit bats may also be destroyed because of their perceived role in causing fruit crop damage.

Hunting seasonal, coinciding with the reproductive aggregations of bats \& has adversely impacted populations, especially in the Andamans, which has a more sedentary non-tribal population than the Nicobars.

In south India $P$. giganteus eaten at least as regularly as other types of bushmeat \& traded locally. Such trade is not of great economic importance \& there is no evidence that the

consumption of bats poses any threat to populations, particularly in comparison with habitat loss \& roost disturbance.

Eaten by some tribes. 


\begin{tabular}{|c|c|c|c|c|c|c|c|}
\hline $\begin{array}{l}\text { Region \& } \\
\text { country }\end{array}$ & Consumption $^{1}$ & $\begin{array}{l}\text { Extent } \\
\text { of } \\
\text { trade }^{2}\end{array}$ & $\operatorname{Taxa}^{3}$ & $\begin{array}{l}\text { Hunting } \\
\text { methods }\end{array}$ & $\begin{array}{l}\text { Legal } \\
\text { controls }{ }^{5}\end{array}$ & References $^{6}$ & Summary \\
\hline $\begin{array}{l}\text { Pacific } \\
\text { Islands }\end{array}$ & & & & & & & $\begin{array}{l}\text { Some species severely impacted by } \\
\text { hunting. }\end{array}$ \\
\hline $\begin{array}{l}\text { American } \\
\text { Samoa }\end{array}$ & 4 & 1 & Pteropus samoensis, Pteropus tonganus & $\mathrm{X}$ & $\mathrm{X}$ & $\begin{array}{l}\text { Cox, 1983; Craig \& Syron, 1992; Craig } \\
\text { et al., 1994a,b; American Samoa Code } \\
\text { Annotated, 1995; Brooke, } 2001\end{array}$ & $\begin{array}{l}\text { Fruit bat populations declined by } 80- \\
90 \% \text { over } 5 \text { years, mainly near human } \\
\text { habitation, because of losses from } \\
\text { cyclones, land clearance } \& \text { subsequent } \\
\text { overhunting by villagers. }\end{array}$ \\
\hline $\begin{array}{l}\text { Cook Islands } \\
\text { \& Niue }\end{array}$ & 4 & 1 & P. tonganus & $\mathrm{X}$ & $\mathrm{X}$ & $\begin{array}{l}\text { Krzanowski, 1977; Wodzicki \& Felten, } \\
\text { 1980; Brooke \& Tschapka, } 2002\end{array}$ & Evidence of overhunting. \\
\hline $\begin{array}{l}\text { Federated } \\
\text { States of } \\
\text { Micronesia }\end{array}$ & 2 & 1 & Pteropus mariannus ulithiensis & 1,2 & $\mathrm{X}$ & Falanruw \& Manmaw, 1992 & Some harvesting for subsistence use. \\
\hline Fiji & 3 & 1 & $\begin{array}{l}\text { Notopteris macdonaldii, Pteralopex } \\
\text { acrodonta, } P \text {. samoensis, } P \text {. tonganus, } \\
\text { Pteropus vetulus, Tadarida bregullae }\end{array}$ & $\mathrm{X}$ & $\mathrm{X}$ & Flannery, 1995b & $\begin{array}{l}\text { Popular with locals \& immigrant } \\
\text { Chinese. }\end{array}$ \\
\hline $\begin{array}{l}\text { Guam \& } \\
\text { Common- } \\
\text { wealth of } \\
\text { Northern } \\
\text { Mariana } \\
\text { Islands }\end{array}$ & 4 & 3 & $\begin{array}{l}\text { Pteropus insularis, Pteropus mariannus, } \\
\text { Pteropus molossinus, Pteropus } \\
\text { phaeocephalus }\end{array}$ & 1 & $\mathrm{X}$ & $\begin{array}{l}\text { Wheeler, 1980; Lemke, 1986; Wiles \& } \\
\text { Payne, 1986; Wiles, 1987; Wiles et al., } \\
\text { 1989; Wiles, 1990, 1992; Wiles et al., } \\
\text { 1997; Utzurrum et al., 2003; Banack } \\
\text { et al., in press }\end{array}$ & $\begin{array}{l}\text { Combination of hunting \& cyclones } \\
\text { resulted in population declines on } \\
\text { many of these islands in the last } 20 \\
\text { years. The only large \& stable bat } \\
\text { populations probably occur on the } \\
\text { remote \& inhospitable islands north } \\
\text { of Farallon de Medinilla. Import of } \\
\text { bats to satisfy Guam's needs for food } \\
\text { has caused population declines on } \\
\text { other Pacific islands. }\end{array}$ \\
\hline $\begin{array}{l}\text { New } \\
\quad \text { Caledonia }\end{array}$ & 4 & 2 & $\begin{array}{l}\text { Pteropus ornatus, } P \text {. tonganus, } \\
P . \text { vetulus }\end{array}$ & 1,3 & $\mathrm{X}$ & Province Sud Nouvelle-Caledonie, 2003 & $\begin{array}{l}\text { Local consumption of bat meat } \\
\text { considered a problem. }\end{array}$ \\
\hline $\begin{array}{l}\text { Solomon } \\
\text { Islands }\end{array}$ & 2 & 1 & Pteropus rayneri, cave-dwelling bats & $\mathrm{X}$ & $\mathrm{X}$ & $\begin{array}{l}\text { Richardson, 1996; Bowen-Jones et al., } \\
1997\end{array}$ & Cave-dwelling species hunted. \\
\hline & 2 & 1 & 12 native bat species & 3 & $\mathrm{X}$ & Chambers \& Esrom, 1991 & $\begin{array}{l}\text { Important element of the diet of } \\
\text { villagers. }\end{array}$ \\
\hline $\begin{array}{l}\text { Western } \\
\text { Indian } \\
\text { Ocean }\end{array}$ & & & & & & & $\begin{array}{l}\text { On some islands extent of hunting of } \\
\text { bats for bushmeat remains a serious } \\
\text { concern. }\end{array}$ \\
\hline
\end{tabular}


Goodman, 2006; Durbin, 2007;

In rural areas three endemic fruit bats Goodman et al., 2008; Jenkins \& Racey, may be the most important bushmeat in press

species after tenrecs Tenrec ecaudatus \& high offtake poses a serious threat to some bat bat populations.

Insectivorous bats also extensively exploited, with some colonies reduced in size or abandoned because of hunting.

Comoros

Islands

Mauritius

Rodrigues

Seychelles

Sub-Saharan

Africa
Pteropus livingstonii, Pteropus seychellensis comorensis

Pteropus niger

Pteropus rodricensis

Pteropus seychellensis
Racey, 1979; Nicoll \& Racey, 1981; Hutson, 1997

Wilson \& Wilson, 1991; Bennett Hennessey, 1995

Colyn et al., 1987

\section{a source of food.}

Traditionally eaten but not currently

Traditionally eaten but not currently a source of food.

Widely eaten, including in hotels \& restaurants.

Although there are few published studies most reports of bat

consumption are from West Africa, where bats have been traditionally eaten and hunted. Eidolon extensively hunted \& some populations decreasing.

Large fruit bats regularly eaten, but no evidence of population decline.

Hunting appears to have little impact on bat populations.

Fruit bats appear to be a less preferred bushmeat.

Rarely eaten.

Fruit bats eaten seasonally. 
Table 1 (Continued)

\begin{tabular}{|c|c|c|c|c|c|c|c|}
\hline $\begin{array}{l}\text { Region \& } \\
\text { country }\end{array}$ & Consumption $^{1}$ & $\begin{array}{l}\text { Extent } \\
\text { of } \\
\text { trade }^{2}\end{array}$ & $\mathrm{Taxa}^{3}$ & $\begin{array}{l}\text { Hunting } \\
\text { methods }\end{array}$ & $\begin{array}{l}\text { Legal } \\
\text { controls }^{5}\end{array}$ & References $^{6}$ & Summary \\
\hline Ethiopia & 1 & 1 & Not known & $\mathrm{X}$ & $\mathrm{X}$ & & $\begin{array}{l}\text { Hunted because of negative } \\
\text { perception amongst local } \\
\text { communities. No evidence of } \\
\text { consumption. }\end{array}$ \\
\hline Gabon & 2 & 2 & Not known & $\mathrm{X}$ & $\mathrm{X}$ & Steel, 1994; Pearce, 1996 & $\begin{array}{l}\text { Eaten only occasionally \& less popular } \\
\text { than other bushmeat. }\end{array}$ \\
\hline Guinea & 4 & 2 & $\begin{array}{l}\text { Rhinolophus maclaudi, Rhinolophus } \\
\text { ruwenzorii }\end{array}$ & $\mathrm{X}$ & $\mathrm{X}$ & Fahr et al., 2002; Fahr \& Ebigbo, 2003 & $\begin{array}{l}\text { Cave-dwelling species particularly } \\
\text { threatened. }\end{array}$ \\
\hline Liberia & 3 & 2 & E. helvum & 3 & $\mathrm{X}$ & Anstey, 1991 & Regularly consumed \& traded. \\
\hline Mali & 2 & 1 & Not known & $\mathrm{X}$ & $\mathrm{X}$ & & Single report of consumption. \\
\hline Nigeria & 3 & 2 & E. helvum, E. franqueti, $H$. monstrosus & $\mathrm{X}$ & $\mathrm{X}$ & $\begin{array}{l}\text { Folorunso \& Okpetu, 1975; Halstead, } \\
\text { 1977; Adeola \& Decker, 1987; Nigeria } \\
\text { Federal Department of Forestry, } 1987\end{array}$ & $\begin{array}{l}\text { Consumption widespread. Some } \\
\text { controlled hunting. }\end{array}$ \\
\hline South Africa & 2 & 1 & Rhinolophus spp. & $\mathrm{X}$ & $\mathrm{X}$ & & Occasional hunting. \\
\hline $\begin{array}{l}\text { Tanzania } \\
\text { (Pemba) }\end{array}$ & 4 & 1 & E. helvum, Pteropus voeltzkowi & $1,3,4$ & $\mathrm{X}$ & $\begin{array}{l}\text { Hutson, 1991; Seehausen, 1991; } \\
\text { Entwistle \& Corp, 1996, } 1997\end{array}$ & Hunting widespread. \\
\hline Uganda & 2 & 2 & E. helvum & 4 & $\mathrm{X}$ & $\begin{array}{l}\text { Ogilvie \& Ogilvie, 1964; Monadjem } \\
\text { et al., } 2007\end{array}$ & $\begin{array}{l}\text { Some local hunting in eastern } \\
\text { Uganda. }\end{array}$ \\
\hline $\begin{array}{l}\text { Zambia } \\
\text { (West) }\end{array}$ & 2 & 1 & E. helvum & $\mathrm{X}$ & $\mathrm{X}$ & & Eaten by local people in the west. \\
\hline $\begin{array}{l}\text { South } \\
\text { America }\end{array}$ & & & & & & & $\begin{array}{l}\text { Little evidence of use of bats as } \\
\text { bushmeat in the Americas. }\end{array}$ \\
\hline Brazil & 2 & 1 & Three phyllostomid species & $\mathrm{X}$ & $\mathrm{X}$ & $\begin{array}{l}\text { Lévi-Strauss, 1979; Setz \& Sazima, 1987; } \\
\text { Setz, } 1991\end{array}$ & $\begin{array}{l}\text { Regular consumption by a few native } \\
\text { tribes. }\end{array}$ \\
\hline
\end{tabular}

${ }_{1}^{1}$, No evidence of consumption; 2, Rarely eaten, no major threat; 3, Regularly eaten, no apparent threat; 4, Regularly eaten, probably serious threat

${ }^{2} 1$, No internal or external trade; 2, Internal but no external trade; 3 , Internal \& external trade

${ }^{3}$ Where known, individual species are identified. In some cases, the information given is more general, referring to genera or particular groups of bats (e.g. cave-dwelling species).

${ }^{4} 1$, Firearms/airguns; 2, Nets; 3, Direct killing; 4, Other; X, No information (see also Table 3)

1, Well controlled; 2 Limited control; 3, No known control of hunting. X, No information

${ }^{6}$ Refers to published information. Where no reference is shown the information has come from the returned questionnaires and anecdotal information. 
TAвLE 2 Geographical distribution of reports on bat consumption and any perceived problems. This is based on 138 records, including questionnaires (Appendix 1) returned and anecdotal information provided. Only regions where there was evidence of significant consumption of bats have been included in our analysis.

\begin{tabular}{|c|c|c|c|c|c|}
\hline \multirow[b]{2}{*}{ Geographical region } & \multirow[b]{2}{*}{ Total no. of reports } & \multicolumn{2}{|c|}{ Consumption reported } & \multicolumn{2}{|c|}{ Perceived problem? } \\
\hline & & Yes & No & Yes & No \\
\hline \multicolumn{6}{|l|}{ Regions included } \\
\hline South-East Asia & 39 & 39 & 0 & 24 & 15 \\
\hline East \& South Asia & 13 & 8 & 5 & 2 & 11 \\
\hline Pacific Islands & 6 & 4 & 2 & 4 & 2 \\
\hline Western Indian Ocean & 14 & 11 & 3 & 5 & 9 \\
\hline Sub-Saharan Africa & 25 & 16 & 9 & 9 & 16 \\
\hline South America & 12 & 2 & 10 & 0 & 12 \\
\hline \multicolumn{6}{|l|}{ Regions excluded } \\
\hline Eurasia* $^{*}$ & 15 & 0 & 15 & 0 & 15 \\
\hline North Africa & 2 & 0 & 2 & 0 & 2 \\
\hline Arabian Peninsula & 1 & 0 & 1 & 0 & 1 \\
\hline Australia & 1 & 1 & 0 & 0 & 1 \\
\hline New Zealand & 2 & 0 & 2 & 0 & 2 \\
\hline North America & 1 & 0 & 1 & 0 & 1 \\
\hline Central America & 5 & 1 & 4 & 0 & 5 \\
\hline Caribbean & 2 & 0 & 1 & 0 & 1 \\
\hline
\end{tabular}

${ }^{\star}$ Includes all of Europe, Russia and former Soviet Republics

from the same village (Johnson et al., 2003). However, some bat species were not locally perceived as threatened; less than $1 \%$ of households surveyed in Nam Ha thought Cynopterus sphinx was decreasing in abundance (Johnson et al., 2003).

Malaysia Bats are regarded as a luxury meat in cities. Most vendors surveyed by Fujita \& Tuttle (1991) reported selling 200-300 bats per season at USD 2.50-3.30 each. There have been severe declines in the abundance and distribution of P. vampyrus throughout Peninsular Malaysia, with most extant colonies located deep in isolated and inaccessible forests and in dense riparian vegetation. Populations of P. vampyrus in eastern Malaysia are also declining (MohdAzlan et al., 2001).

Malaysia (Peninsular Malaysia) The Department of Wildlife and National Parks sells permits, each allowing 50 $P$. vampyrus to be shot, and about 40 such permits were issued in 1 year in Perak. Mohd-Azlan et al. (2001) calculated that permits to shoot 56,000 P. vampyrus were issued between 1990 and 1996.

Malaysia (Sabah and Sarawak) In Sarawak hunting occurred mostly during the bats' reproductive season (Fujita, 1988). Cheiromeles torquatus was opportunistically captured at roosts by indigenous people. The Iban of Sarawak could net up to 200 bats per night. Bats may also be shot for sport or to eradicate them from fruit plantations (Fujita \& Tuttle, 1991). Although few traders specialized in bat meat, one vendor in Sarawak sold 150-200 bats per week at c. USD 3 each, hunted by the Iban and sold to Chinese customers. Non-specialist vendors were estimated to sell a few thousand per year. Bat trade may thus be economically important to at least some Iban.
Myanmar Local boys at Nadkon village cave, and cement factory workers at Saddan-Sin cave, both in Kayon state, collect whatever species they can for consumption. In at least one location (Nagamauk Cave) hunting stops during the breeding season. Bats are only traded locally to supplement income. For example, in Kyauk-Ta-Lone village, $1 \mathrm{~kg}$ of bats may be sold for c. USD 1 (Bates, 2003). Bat populations are probably not threatened by hunting, although impacts may vary according to attitudes in each village. Many cave roosts in Myanmar, especially larger ones, are protected from overharvesting by local communities, to ensure the supply of guano (Bates, 2003).

New Guinea (Papua New Guinea and Irian Jaya) The Hatam, a local tribe of the northern Arfak Mountains of Irian Jaya, eat both fruit and insectivorous bats. Bats are also an additional source of protein for those practising slash-and-burn agriculture. Fruit bats were probably unsustainably harvested by at least one group (Cuthbert, 2003a). In one village of c. 1,000 people 100-150 bats were taken per year. When one large roost site was protected by these villagers its bat population increased. Elsewhere, harvesting levels by other groups, such as the Hagahai, may be sustainable (Hladick et al., 1993). The decline and possible extinction of Aproteles bulmerae at Luplupwintem cave in the 1970 s was probably because of the effects of hunting with guns (Flannery, 1995a). In the early 1990 s hunting was thought to have caused the numbers of Dobsonia moluccensis in a large cave near Herowana to fall from many thousands to c. 200 (Cuthbert, 2003b). Villagers voluntarily agreed to stop hunting bats in the large cave and to harvest from small caves or take foraging individuals. Counts of emergent individuals at the cave in 
TABLE 3 A summary of different methods used to hunt bats and the geographical areas where these are known to be deployed.

\begin{tabular}{|c|c|}
\hline Method & Where used \\
\hline Nets or barbed burrs of Uncarina grandidieri & Madagascar \\
\hline Firearms (rifles, guns, etc.) & $\begin{array}{l}\text { Across much of Africa, Madagascar, Benin, Cameroon, Tanzania } \\
\text { (Pemba Island), China, India, India (Karnataka), Indonesia (Irian } \\
\text { Jaya), Malaysia, Philippines, Pacific States, New Caledonia }\end{array}$ \\
\hline Airguns & $\begin{array}{l}\text { India (Andamans \& Nicobars), Philippines, Federated States of } \\
\text { Micronesia (Ulithi Atoll) }\end{array}$ \\
\hline Smoking out of roosts (E. dupreanum) & Madagascar \\
\hline Smoking out of roosts & China, Indonesia, Philippines \\
\hline Using birdlime (a sticky adhesive smeared on branches) & India \\
\hline Sticky forked sticks outside caves & Malaysia (Sarawak) \\
\hline Mist nets & China, India (Karnataka), Lao PDR \\
\hline Nets & $\begin{array}{l}\text { Indonesia (Sanguhe Island), Indonesia (north Sumatra), Indonesia } \\
\text { (Sulawesi), Malaysia (Sarawak), Thailand, Vietnam, Yap }\end{array}$ \\
\hline Nets at roosts or fruit trees & Madagascar, Benin, Cameroon (Mount Cameroon) \\
\hline Nets set over cave entrances & Myanmar, Philippines, Thailand \\
\hline Fishing nets hoisted into feeding trees & Philippines \\
\hline Nets or nylon lines with fishing hooks suspended between trees & Seychelles, Indonesia (north Sumatra) \\
\hline Hooked ropes suspended through feeding trees & Malaysia, Philippines \\
\hline Kites with hooks & Malaysia (Sarawak) \\
\hline Nets tied to long poles to trap at boma trees (E. helvum) & Cameroon (Bomboko) \\
\hline Nets on end of bamboo poles & India \\
\hline Bamboo poles with thorns or fish hooks on the end & Philippines (Palawan) \\
\hline Catapaults or slingshots & $\begin{array}{l}\text { Comoros, Benin, Cameroon (Mount Cameroon), Cambodia, Lao } \\
\text { PDR, Tanzania (Pemba Island), Philippines }\end{array}$ \\
\hline Killing whilst emerging from roost trees & Congo (Kasai) \\
\hline Killing whilst emerging from caves (D. moluccensis) & Indonesia (Irian Jaya) \\
\hline Bow \& arrow (E. helvum) & Liberia (Sinoe County) \\
\hline Bow \& arrow & Vanuatu, New Caledonia \\
\hline Crossbow & New Caledonia \\
\hline Thorny bushes & Congo (Kasai), Tanzania (Pemba Island), Philippines \\
\hline Hitting with sticks & $\begin{array}{l}\text { Tanzania (Pemba Island), Lao PDR (Nam Ha), Thailand (Phu } \\
\text { Kheio), Vietnam }\end{array}$ \\
\hline Hitting with branches whilst roosting & Indonesia (Irian Jaya) \\
\hline Stoning & Uganda (east) \\
\hline Using snares & Uganda (east), Indonesia (Sanguhe Island) \\
\hline $\begin{array}{l}\text { Using nylon rope to reach previously inaccessible roosts }(A \text {. } \\
\text { bulmerae) }\end{array}$ & New Guinea \\
\hline Funnel trap to catch bats emerging from caves & Lao PDR \\
\hline Bait \& hook & Lao PDR \\
\hline Sitting on posts \& catching with hand nets & Vietnam (Thanh Hoa) \\
\hline Collecting by hand & Lao PDR \\
\hline
\end{tabular}

1992, 1995, 1996 and 2003 showed a clear rise in bat numbers, demonstrating the possibility of sustainable bat hunting (Cuthbert, 2003b).

Philippines P. vampyrus and Acerodon jubatus are preferred because of their larger size. Different species are important in different areas: for example, Dobsonia chapmani may be preferred in Negros but insectivorous bats are preferred in Montalban, Luzon. In south-western Negros bat meat is second in importance to herpetofauna but in the Tagbanua community in south Palawan it represents only $5 \%$ of game caught (Lacerna \& Widmann, 1999). There is some local bat meat trade that may involve people living far away from roosts. Although 150,000 bats were counted at roosts in the late 1920s, no group larger than a few hundred was observed by Heaney \& Heideman in 1987. After it was thought to have been hunted out of caves in Negros $>30$ years ago (Heaney \& Heideman, 1987) D. chapmani was recently rediscovered (Simmons, 2005). Most hunters kill only a few bats per trip but those operating at roost sites take hundreds in a single hunt. In Palawan poorer households hunt more frequently, with bats being the target of many hunting trips and harvest rates are high (Shively, 1997). Some communities in south-western Negros may collect as many as $300-1,000$ bats in a week during the rainy season, amounting to $1,500-5,000$ in a summer. A. jubatus 
has also undergone a dramatic decline as it is both a forest specialist and is heavily hunted (Mildenstein et al., 2002). The government now recognizes the threat that hunting poses to wildlife and it has been banned for all but indigenous minorities who use traditional methods, although enforcement is weak. Some local people try to selectively hunt the larger Pteropus species, and others may recognize but ignore population declines. In areas of north-west Panay and Boracay, Frankfurt Zoological Society's Endemic Species Conservation Project (PESCP) has encouraged local recognition of the threats facing wildlife, including bats. PESCP has also successfully reduced hunting through an anti-gun campaign, where firearms can be exchanged for rice or cash. In addition there is a flying fox conservation and monitoring programme, with over 60 groups protecting individual roosts. Dietary studies by Stier (2003) suggest that although bats have catholic diets, A. jubatus prefer Ficus subcordata, and educating hunters to reduce hunting at these fig trees could effectively reduce the take of A. jubatus.

Thailand Bats were eaten by $7 \%$ of households in Phu Kheio sanctuary (Magnus, 2001). Some, including the world's smallest species Craseonycteris thonglongyai, may also be dried and sold as souvenirs (Robinson, 1993, 1995). The introduction of foreign aid and improvement in the transport infrastructure in the 1960 s meant Rousettus could be hunted in caves in the Bangkok area and traded and sold in restaurants. This resulted in dramatic declines and a drop in guano production such that communities previously economically reliant on it broke up (Stebbings, 1987). Several species were sold (USD 0.20 each) in the daily market in Chiang Khan, north-east Thailand, sometimes live, impaled through their wings to prevent escape (Robinson, 1994); some may have come from Lao PDR, indicating crossborder trade. In remoter areas, such as villages in Phu Kheio sanctuary, bats may only be sold if a hunter happens to catch a surplus (Magnus, 2001). When limestone quarrying and hunting came close to exterminating Eonycteris spelaea, awareness of their role in the pollination of durian, lobbying by conservationists, and the views of religious leaders who regarded caves as sacred, resulted in legal protection of the main caves and the bats (Stebbings, 1987). All insectivorous bats and four species of Pteropus are protected by the Wildlife Preservation and Protection Act 1992, although enforcement is weak and roost sites are unprotected. Guano production may also provide an incentive for some communities to try to protect their bats at a local level, although this may not always be successful (Robinson, 1993).

Vietnam Bat consumption is probably less intense than in neighbouring Thailand, especially in the north. Despite extensive surveys into hunting and wildlife trade in Hanoi, only one incident of bat consumption (in Con Cuong district) has been reported. In Kho Muong village in Thanh Hoa Province, bats were collected for food from the local bat cave for 10 days at the beginning of September, with villagers sitting on posts to catch bats using hand-held nets (Thong, 2004). Trade or sale of bats in restaurants is generally not recorded in urban areas or in the north but it has been noted in the Mekong region where there are several restaurants selling fruit bats. At least one cave-roost at Hang Doi Kho Muong in northern Vietnam has declined because of hunting (Thong, 2004). Bat hunting is the greatest threat to bat populations inhabiting Pu Luong Nature Reserve in north-central Vietnam (Thong, 2004). For example, in Kho Muong village local people estimate that c. 1,00o kg of bats were collected from the local bat cave during the annual harvest; the numbers collected declined steadily from 1977 and a recent survey found only a small colony in the cave (Thong, 2004). Perceptions of threats posed by hunting vary; some consider it poses a threat to bat populations, whereas others report that harvesting is limited to avoid depleting large colonies and that Miniopterus spp. and Tadarida plicata have been regularly harvested with no observed impact. The Fauna \& Flora International Vietnam programme has recorded caveroosting bat declines in northern Vietnam and is promoting conservation action on this issue and awareness amongst the local people. In Pu Luong Nature Reserve measures to combat bat consumption were recommended by Thong (2004). After the establishment of this reserve, Kho Muong village was requested to end bat harvesting at the local bat cave but recent surveys found few bats inside, indicating either problems with compliance or ineffective management.

\section{East and South Asia}

Bangladesh Some tribal people occasionally eat Pteropus giganteus.

China In some areas bats are rarely consumed and always less so than other bushmeat species. In southern China however, bat meat is traded locally and regionally; it appears on some restaurant menus in Guangdong and Guangxi provinces, especially in Wuming County. Bats were seen in markets during surveillance linked to the SARS epidemic in 2003. Bats are not specifically protected in mainland China although proposed tougher wildlife laws, in response to SARS, may ban the consumption of bushmeat.

India (mainland) Bats receive no statutory protection and are classed as vermin (Singaravelan et al., in press). No bat consumption has been observed in Arunachal Pradesh, north-east India, despite extensive surveys that identified the consumption of more than 40 bushmeat species. However, the aboriginal people of remote Indian forests may eat $P$. giganteus, although in smaller quantities than other 
bushmeat. Anglo-Indians and aboriginal people regularly eat bat meat in Visakhapatnam and Srikakulam Districts. In India most bat meat is for private consumption.

India (Andaman \& Nicobar Islands) Pteropus melanotus and Pteropus faunulus are frequently hunted at night, at their foraging and roosting trees, for consumption on special occasions.

Nepal The Chepang, Newar, Tamang and Bahun Chetri tribes use bats for food.

\section{Pacific Islands}

American Samoa There are several reports of consumption of the two fruit bat species Pteropus tonganus and Pteropus samoensis (Cox, 1983; Craig et al., 1994a,b; Brooke, 2001). There are two relevant legislative measures: in 1986 exportation and commercial hunting was prohibited and subsistence hunting limited (Craig \& Syron, 1992) and a 3-year hunting ban was initiated in 1992, later extended to aid population recovery after Cyclones Ofa and Val (American Samoa Code Annotated, 1995). However, regulations may be poorly known and enforced (Craig et al., 1994b) and export of bats to Guam may continue illegally.

Cook Islands \& Niue Bats are regarded as a great delicacy in the Cook Islands, Niue and Mangaia (Krzanowski, 1977; Brooke \& Tschapka, 2002) and Rarotonga (Wodzicki \& Felten, 1980). On Niue fruit bats were hunted in an annual 2-month period that coincides with the bats' reproductive season (Wodzicki \& Felten, 1980; Brooke \& Tschapka, 2002). On Niue Brooke \& Tschapka (2002) suggested P. tonganus was overhunted in 1998, when 1,555 were shot by 60 hunters.

Federated States of Micronesia On Ulithi Atoll in the Caroline Islands, although some people may harvest Pteropus mariannus ulithiensis for subsistence use, only a few bats were taken and they were not highly regarded (Falanruw \& Manmaw, 1992).

Fiji Bat consumption is popular with local people and immigrant Chinese. The relationship between hunting and population declines is challenged by reports from Fiji, which suggest that although bats are intensively hunted Pteropus vetulus remains common (Flannery, 1995b). Threats from deforestation are considered more important.

Guam \& the Commonwealth of the Northern Mariana Islands Pteropus meat in Guam is in high demand (e.g. Wiles, 1987, 1992). Its popularity with wealthy residents, as well as preparation methods, are described by Lemke (1986). The Chamorros, indigenous to the Marianas, consider it a great delicacy and serve it on special occasions (Wiles, 1990), paying up to USD 30 for a single bat (Wiles \& Payne, 1986) despite the fact that eating it may result in a neurogenerative disease (Banack et al., in press). On Guam
Pteropus tokudae has become extinct and populations of Pteropus mariannus have declined severely (Wiles et al., 1989). Many Pacific islands have supplied Guam with fruit bats, including American Samoa, Palau, Commonwealth of the Northern Mariana Islands, Federated States of Micronesia, Fiji, Indonesia, Papua New Guinea and the Philippines. The decline of fruit bats on Rota, Tinian and Saipan was probably accelerated by harvests to supply Guam's market (Wheeler, 1980). Wiles et al. (1997) reported that 180,00o P. mariannus pelewensis were shipped from Palau to Guam during 1975-1994. In 1989 CITES regulations were amended, with all Pteropus and Acerodon species included in Appendix I or II. The seven most threatened species of Pteropus, including P. mariannus, were placed in Appendix I. These amendments were primarily a response to trade in fruit bats across the Pacific to satisfy demand in Guam. Across this area there are also several pieces of local legislation that aim to regulate fruit bat harvesting or trade. For example, in 1984 P. mariannus was declared Endangered on Guam by the US Fish and Wildlife Service. Initially, CITES regulations were not properly enforced but with the arrival of a US Fish and Wildlife Service Inspector, Guam's imports in 1990 dropped from 3,989 during January-March to 292 in May-June (Wiles, 1990). However, imports from other US territories then increased as CITES could not regulate this internal trade. The use of other legislation has been necessary to enforce the trade limitation: for example, the situation in Palau was controlled through application of the Lacey Act that prohibits the inter-state transport of illegally killed wildlife (Wiles, 1990). Loopholes in the law have been exploited, to the detriment of bat populations. In the Commonwealth of the Northern Mariana Islands there are special authorizations for bat hunts for two special festivals. However, at these times the quota of $10-15$ is exceeded, with hundreds being killed, and there is evidence that bats harvested on Rota may be traded to people on other islands. The small closeknit communities of these islands also make it difficult for local police to enforce this unpopular law (Lemke, 1986). Lemke (1986) concluded that $75 \%$ of fruit bat colonies on Rota had declined, and populations on Saipan had declined to $<25$ bats, and on Tinian and Aguijan there were $<10$ bats on each island. All three islands supported hundreds, if not thousands, of bats as recently as 10 years earlier.

New Caledonia In the Southern Province bat hunting is allowed only on weekends in April, with a maximum allowed catch of five per hunter per day (Province Sud Nouvelle-Caledonie, 2003).

Solomon Islands About 1,00o bats per month have been taken from limestone cave systems as an alternative protein to fish (Richardson, 1996) and fruit bat is an 'occasional treat' on the remote island of Choiseul (Bowen-Jones et al., 1997). 
Vanuatu The 12 bat species are the only native mammals. A questionnaire-based investigation (Chambers \& Esrom, 1991) reported that fruit bats were eaten by villagers and $85 \%$ described them as important in the diet. Only one group did not eat fruit bats, because they regarded them as ancestors.

\section{Western Indian Ocean}

Madagascar Pteropus rufus was listed as vermin in 1961. In 1988, after the CITES listing of Pteropus, all Malagasy bats were classed as game and can be legally hunted within a defined season, which is May-October for fruit bats (Durbin, 2007). Despite this, bats are hunted for food throughout the year with both seasonal and geographical patterns of exploitation. There is a small amount of regional trade but most bats are sold locally or are eaten as subsistence food. The extent of hunting of $P$. rufus has resulted in a recently revised Red List categorization of Vulnerable (Mackinnon et al., 2003; IUCN, 2008; Jenkins \& Racey, 2008). There is evidence that bat bushmeat is an important source of food for people living with low food security (Goodman, 2006) and that over a dozen species are exploited for bushmeat throughout the island, although one was cooked and fed to pigs (Goodman et al., 2008; Cardiff et al., in press).

Islands \& Archipelagos Pteropus subniger became extinct in the Mascarene Islands in the 19th century due in part to overhunting. Although $P$. rodricensis and $P$. niger have traditionally been hunted for food on Rodrigues and Mauritius, respectively, they are no longer eaten. As a Critically Endangered species, $P$. rodricensis is protected, although such protection may be removed from $P$. niger because of its perceived role in damaging litchi crops. In the Seychelles in the 1970 s there was concern about the declining numbers of $P$. seychellensis, which were hunted for food. However, all guns were then confiscated and bat numbers rose (Racey, 1979; Nicoll \& Racey, 1981). P. seychellensis remains a common item in supermarkets (Hutson, 1997; S. Remie, pers. comm.) and was served by a third of 65 hotels and restaurants surveyed (C. Uzice, pers. comm.). Hutson (1997) also reported that although consumption was the main threat to bats, populations were still healthy. On the Comoros Islands P. seychellensis comorensis is eaten only occasionally and not by all ethnic groups. The threatened $P$. livingstonii is less likely to be eaten, because of its rarity and because it is not perceived as so much of a threat to crops (Trewhella et al., 1995; Sewall et al., 2004).

Sub-Saharan Africa Benin Larger fruit bats, such Eidolon helvum and Epomophorus spp., are preferred and are seen in markets, although they are probably not a regular dietary component. Bats have also been bought in a Togolese market near the Benin border by people from Benin.
Cameroon Consumption of fresh or smoked bat occurs, usually by only a few people or as an irregular component of the diet. E. helvum is a delicacy in the Bomboko area where it can be a major source of income at peak harvesting season, when it is sold for local consumption and to restaurants. Bat meat is traded both locally and regionally. Overall, bat consumption is considered negligible, especially in comparison to other bushmeat.

Congo Republic Most bat meat is hunted for family consumption, although in south-west Congo three of five market surveys conducted by Wilson \& Wilson (1991) found E. helvum being traded and eaten at a price lower than any other bushmeat. Bennett Hennessey (1995) also found that fruit bats retailed for a low price in Ouesso, where they are still readily available in markets (R. Ruggiero, pers. comm.).

Côte d'Ivoire E. helvum consumption was observed by one correspondent in the 1980 s.

Democratic Republic of Congo In a bushmeat survey in an urban market in Kisangani, Colyn et al. (1987) made 2,475 observations of E. helvum and Epomops franqueti out of a total of 73,948 observations of all types of bushmeat. E. helvum is abundant seasonally in bushmeat markets in Kisangani and Hypsignathus monstrosus is also sold (Plate 1).

Equatorial Guinea Jones (1972) noted that the only major predator of E. helvum, E. franqueti and Micropteropus pusillus was humans, and Heymans (1994) also described hunting of E. helvum and Hipposideros spp., although bats were not among the top 35 species preferred by consumers. On Bioko E. helvum and Rousettus aegyptiacus were hunted although they were not the main bushmeat species targeted (Fa, 2000). Fa et al. (1995) and Juste et al. (1995) showed that bat consumption could occur without trade (Jones, 1972), perhaps reflecting the relative unpopularity of bat meat compared with larger mammal species (Heymans, 1994).

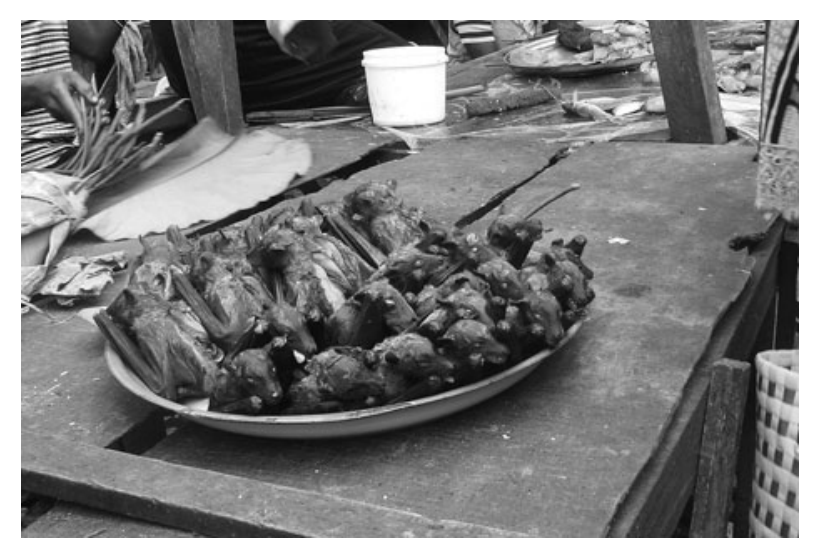

Plate 1 Straw-coloured fruit bats Eidolon helvum (with a single hammer-headed bat Hypsignathus monstrosus in the centre) for sale in the market in Kisangani, Democratic Republic of Congo (photograph by Guy-Crispin Gembu Tungaluna). 
Ethiopia The only respondent mentioned bats being heavily hunted because of peoples' hatred of them, and this may have contributed to local extinctions.

Gabon One respondent reported bat consumption. However, bats are eaten only occasionally and are less popular than other bushmeat species.

Guinea One respondent noted that all species of bats are hunted in caves for consumption on special occasions, although no bat consumption was noted by Fahr \& Ebigbo (2003). Fahr et al. (2002) noted that cave roosts of Rhinolophus maclaudi in Upper Guinea were 'increasingly exploited' and $R$. ruwenzorii roosting in caves were vulnerable to exploitation. Entire populations of cave-dwelling bats could be killed in one visit. Although hunting is carried out only twice per year a detrimental impact on bat populations is likely.

Liberia E. helvum is regularly consumed and traded but they are the lowest priced item and constituted only $0.25 \%$ of items recorded at market (Anstey, 1991).

Mali There is one report of bat consumption at Solo village, near Manantali Dam, in Mali.

Nigeria Bat consumption seems widespread and Folorunso \& Okpetu (1975) published recipes for fruit bats. Halstead (1977) described the harvest of E. helvum at the University of Ife, Nigeria; bats were shot on a weekly basis over OctoberMarch, with approximately 12,000 shot in a season. No more than 600 bats were taken in any one shoot and there was no apparent impact on the colony. Controlled hunting appeared to allow the colony to grow, possibly because of the lessened disturbance and harassment of the bats. Adeola \& Decker (1987) found E. helvum was harvested by rural farmers during the rainy season. Bats were a cheap meat, popular with women from Ife and surrounding areas.

South Africa There appears to be little bat consumption in South Africa although occasional hunting of the small but common Rhinolophus spp. may occur in the Limpopo and Mpumalanga provinces.

Tanzania (Pemba) Although bats are not consumed in mainland Tanzania bat meat is popular on the island of Pemba (Entwistle \& Corp, 1997). There are four fruit bat species and Pteropus voeltzkowi is endemic. It is considered a delicacy and is particularly prominent in the diet in June-July (Entwistle \& Corp, 1996). Entwistle \& Corp (1997) found no evidence that bats were sold but were rather distributed among members of a hunting party for private consumption. Seehausen (1991) described the dramatic decline of $P$. voeltzkowi, comparing past reports of large colonies with the small groups seen in 1989, and attributed this to increasing intensity of hunting as well as habitat destruction. Entwistle \& Corp (1997) found hunting was widespread throughout Pemba, occurring at 13 of 19 occupied roost sites, with signs of recent hunting at five deserted roosts. An education programme led one village to protect their flying fox roost and the number of bats at this roost then apparently increased to become one of the largest on the island (Entwistle \& Corp, 1996). The expansion of this education programme through Environment Clubs has resulted in a decline in hunting and an increase in bat numbers to an estimated 21,000 (S.J. Ali, S.K. Haji \& F.M. Saleh, pers. comm.; Robinson, 2008).

Uganda There was local demand for E. helvum when they were sold at Makerere University in Kampala after a storm blew them to the ground (Ogilvie \& Ogilvie, 1964). However, numbers of E. helvum there declined from 250,000 to 40,000 in 40 years (Monadjem et al., 2007). This species, along with others, is eaten by the Bagisu people in eastern Uganda, where bats are hunted for private consumption.

Zambia In western Zambia local people eat E. helvum (C. Kandunga, pers. comm.).

\section{South America}

Despite the diversity and abundance of bats across tropical America the majority of reports suggest bat consumption is rare. However, a perception of bats as being dangerous can lead to their being hunted with the aim of exterminating populations. There is one report of regular bat consumption by some native tribes, most notably the Nambiquara of western Brazil, who consume three species of phyllostomids (Lévi-Strauss, 1979; Setz \& Sazima, 1987; Setz, 1991). In Brazil all native species are legally protected but bats have traditionally been regarded as dangerous and have been exterminated in many areas.

\section{Discussion}

This review presents clear evidence that bat populations are seriously threatened by hunting for bushmeat in several countries, particularly Indonesia, Malaysia and the Philippines, and several islands in the Indian and Pacific Oceans. Unsurprisingly, the main target species are fruit bats of the genus Pteropus because they are the largest, roost in trees and forage on flowers, leaves or ripe fruit, so that their whereabouts are predictable. Reported levels of offtake in species with such a low reproductive rate is a matter of serious concern. In those mainland African countries in which bats are hunted, it is also the largest fruit bat species, E. helvum, that is targeted, and population declines have also been reported. Although bat faunas are richer in Central and South America the constituent species are small-bodied and there is little to suggest that hunting is widespread or is having a significant effect on populations.

Legislation to protect wildlife in the developing world is seldom effective by itself because of the difficulties of enforcement, and other approaches are necessary. However, 
national legislation to protect bats is preferable because its absence in some countries, such as India, where bats are classed as vermin, inhibits conservation action at some levels (Singaravelan et al., in press). Occasionally, the control of guns and ammunition has proved effective in preventing population declines of bats hunted for food, as in the Seychelles. Education programmes that emphasize the role of bats in providing ecosystem services are now widely implemented (Trewhella et al., 2005; O'Connor et al., 2006, Jenkins et al., 2007). Local communities often resent commercial hunters from outside the community taking bats from their neighbourhood, and community conservation programmes have proved particularly effective in Pemba and Madagascar. The most pressing requirement is for research into sustainable harvesting, particularly because the only managed harvest reported to date, that organized by Halstead (1977) in the campus of Ife University, Nigeria, appeared to have been effective. Voluntary controls of hunting in New Guinea (Cuthbert, 2003b) and Madagascar (Jenkins et al., 2007) have also been successful in halting declines in bat numbers.

The provision of reliable data on changes in population size, to measure the impact of hunting, requires welldesigned monitoring programmes, which are particularly challenging to implement for bats forming large aggregations and moving between roosts. Where such long-term programmes are established, as in Uganda (Monadjem et al., 2007), they have documented declines that are seldom dramatic from year to year but over longer periods become a matter of serious concern. Similar monitoring programmes have been in operation over shorter periods in Madagascar (Jenkins et al., 2007). Long-term monitoring programmes are difficult to sustain in the tropics but are clearly needed.

Considering the widespread nature of hunting, there have been few studies on the relative importance of bats in the diet, i.e. to determine the extent to which it is an expensive luxury reserved for special occasions, as with the Chamorro on Guam, or adds variety to a diet that is not protein deficient. Elsewhere it may be a starvation food, as in south-west Madagascar (Goodman, 2006). Bat consumption driven by preference, rather than need, may require different interventions if conservation is to be successful.

The threat of pathogen transfer from bats to people is of growing concern. The discovery of asymptomatic Ebola virus infections in three species of pteropodids in West Africa (Leroy et al., 2005) raises concerns about the risk to humans of preparing bats for consumption. Appropriate surveillance for the presence of disease should be carried out before sustainable harvesting programmes are encouraged.

In conclusion we recommend: (1) Continuing surveys of the extent to which bats are taken as bushmeat and the incorporation of bats in surveys of general bushmeat consumption, recognizing that the supply chain for bat meat may differ from that for other bushmeat; these surveys should also evaluate the relative importance of bat bushmeat in the diet and the possible health risks of bat consumption. (2) Where none exists, national legislation should be introduced to protect bats or establish closed seasons for hunting, depending on the conservation status of the species concerned. (3) More education projects aimed at publicizing the importance of bats as pollinators and seed dispersers, and their role in forest ecology. (4) More community-based projects aimed at conserving local bat populations or, where appropriate, harvesting them sustainably.

\section{Acknowledgements}

The authors would like to thank all of those who provided information for this review. Their names and geographical areas of expertise are listed in Appendix 2. We would also like to thank Richard Jenkins, Steven Goodman and an anonymous referee for comments on earlier drafts and Nora Morrison at the University of Aberdeen for help in the production of the final manuscript.

\section{References}

Adeola, M.O. \& Decker, E. (1987) Utilisation de la Faune sauvage en milieu rural au Nigeria. Nature et Faune, 3, 15-21.

American Samoa Code Annotated (1995) A.S.C.A. 24.o8, A Rule to Regulate Hunting by Adding Chapter 08 to Title 24 of the American Samoa Administrative Code. Pago Pago, American Samoa.

Anstey, S. (1991) Wildlife Utilisation in Liberia. The Findings of a National Survey 1989-1990. Report for WWF-UK, Godalming, UK.

BAnACK, S.A., Cox, P.A. \& Murch, S.J. (in press) Flying fox consumption and human neurogenerative disease in Guam. In Island Bats (eds T.H. Fleming \& P.A. Racey). University of Chicago Press, Chicago, USA.

B A TES, P.J.J. (2003) Conservation Status of the Bat and Bird Fauna of the Limestone Karst Areas of Mon and Kayin States, Myanmar (Burma). Unpublished Report for Fauna \& Flora International $100 \%$ Fund, Fauna \& Flora International, Cambridge, UK.

Bennett Hennessey, A. (1995) A Study of the Meat Trade in Ouesso, Republic of Congo. Wildlife Conservation Society, New York, USA.

Bergmans, W. \& RozendaAl, F.G. (1988) Notes on collections of fruit bats from Sulawesi and some off-lying islands (Mammalia, Megachiroptera). Verhandlung Leiden, 248, 5-74.

Bowen-Jones, E., Abrutut, D., Markham, B. \& Bowe, S. (1997) Flying foxes on Choiseul (Solomon Islands) - the need for conservation action. Oryx, 31, 209-217.

Bowen-Jones, E., Brown, D. \& Robinson, E. (2002) Assessment of the Solution-orientated Research Needed to Promote a More Sustainable Bushmeat Trade in Central and West Africa. Fauna \& Flora International, Natural Resources Institute, Overseas Development Institute and Department of Environment, Food \& 
Rural Affairs. Produced for DEFRA (DETR), Wildlife \& Countryside Directorate, London, UK.

Bowen-Jones, E. \& Pendry, S. (1999) The threat to primates and other mammals from the bushmeat trade in Africa, and how this threat could be diminished. Oryx, 33, 233-246.

Brooke, A.P. (2001) Population status and behaviours of the Samoan flying fox (Pteropus samoensis) on Tutuila Island, American Samoa. Journal of Zoology, London, 254, 309-319.

B RоOKe, A.P. \& Tsснарка, M. (2002) Threats from overhunting to the flying fox, Pteropus tonganus (Chiroptera: Pteropodidae) on Niue Island, South Pacific Ocean. Biological Conservation, 103, 343-348.

Cardiff, S.G., Ratrimomanarivo, F.H., Rembert, G. \& Goodman, S.M. (in press) Hunting, disturbance and roost persistence of bats in caves at Ankarana, northern Madagascar. African Journal of Ecology.

Cariño, A., Cadeliña, A.M. \& Tiempo, F.A. (2006) An Ethnobiological Survey of Wildlife Hunters on Negros Island, Philippines. Unpublished Report to Bristol, Clifton \& West of England Zoological Society, Bristol, UK, and Fauna \& Flora InternationalPhilippine Biodiversity Conservation Programme, Cambridge, UK.

Chambers, M.R. \& Esrom, D. (1991) The fruit bats of Vanuatu. Bat News, 20, 4-5.

Clayton, L. \& Milner-Gulland, E.J. (2000) The trade in wildlife in north Sulawesi, Indonesia. In Hunting for Sustainability in Tropical Forests (eds J.G. Robinson \& E. Bennett), pp. 473-496. Columbia University Press, New York, USA.

Colyn, M., Dudu, A. \& Mbaelele, M. (1987) Exploitation du petit et moyen gibier des forests ombrophiles du Zaire. Nature et Faune, 3, 22-39.

Cox, P.A. (1983) Observations on the natural history of Samoan bats. Mammalia, 47, 519-523.

Cox, P.A., Elmqvist, T., Pierson, E.D. \& Rainey, W.E. (1992) Flying foxes as pollinators and seed dispersers in Pacific Island ecosystems. In Pacific Island Flying Foxes: Proceedings of an International Conservation Conference (eds D.E. Wilson \& G.L. Graham), pp. 18-23. US Fish and Wildlife Service Biological Report 90(23). US Department of the Interior, Fish and Wildlife Service, Washington, DC, USA.

Craig, P., Morrell, T.E. \& So'Oto, K. (1994a) Subsistence harvest of birds, fruit bats and other game in American Samoa, 1990-1991. Pacific Science, 48, 344-352.

Craig, P. \& Syron, W. (1992) Fruit bats in American Samoa: their status and future. In Pacific Island Flying Foxes: Proceedings of an International Conservation Conference (eds D.E. Wilson \& G.L. Graham), pp. 145-149. US Fish and Wildlife Service Biological Report 90(23). US Department of the Interior, Fish and Wildlife Service, Washington, DC, USA.

Craig, P., Trail, P. \& Morrell, T.E. (1994b) The decline of fruit bats in American Samoa due to hurricanes and overhunting. Biological Conservation, 69, 261-266.

Craven, I. (1988) Finding solutions. BATS, 6, 12-13.

Cuthbert, R. (2003a) The Sustainability of Hunting in Papua New Guinea: A Preliminary Analysis. Unpublished Report for Fauna \& Flora International $100 \%$ Fund, Fauna \& Flora International, Cambridge, UK.

Cuthbert, R. (2003b) The Impact of Hunting on Wildlife Populations in Papua New Guinea: Report 2. Unpublished Report for Fauna \& Flora International $100 \%$ Fund, Fauna \& Flora International, Cambridge, UK.

Durbin, J. (2007) New legislation for the protection of Malagasy species. Lemur News, 11, 4-6.

Entwistle, A. \& Corp, N. (1996) Pemba flying fox. Bat News, 40, $4-5$.
Entwistle, A. \& Corp, N. (1997) Status and distribution of the Pemba flying fox Pteropus voeltzkowi. Oryx, 31, 135-142.

FA, J.E. (2000) Hunted animals in Bioko Island, West Africa: sustainability and future. In Hunting for Sustainability in Tropical Forests (eds J.G. Robinson \& E. Bennett), pp. 168-198. Columbia University Press, New York, USA.

Fa, J.E., Juste, J., Perez de Val, J. \& Castroviejo, J. (1995) Impact of market hunting on mammal species in Equatorial Guinea. Conservation Biology, 9, 1107-1115.

Fahr, J. \& Eвigbo, N.M. (2003) A conservation assessment of the bats of the Simandou Range, Guinea, with the first record of Myotis welwitschii (Gray, 1866) from West Africa. Acta Chiropterologica, 5, 125-141.

Fahr, J., Vierhaus, H., Hutterer, R. \& Kock, D. (2002) A revision of the Rhinolophus maclaudi species group with the description of a new species from West Africa (Chiroptera: Rhinolophidae). Myotis, 40, 95-126.

Falanruw, M.C. \& Manmaw, C.J. (1992) Protection of flying foxes on Yap Islands. In Pacific Island Flying Foxes: Proceedings of an International Conservation Conference (eds D.E. Wilson \& G.L. Graham), pp. 150-154. US Fish and Wildlife Service Biological Report 9o(23). US Department of the Interior, Fish and Wildlife Service, Washington, DC, USA.

Flannery, T. (1995a) Mammals of New Guinea (Revised and Updated Edition). Reed Books, Chatswood, Australia.

Flannery, T.F. (1995b) Mammals of the South-West Pacific \& Moluccan Islands. Reed Books, Chatswood, Australia and Cornell University Press, Ithaca, USA.

Folorunso, T.A. \& Oкретu, F. (1975) Fruit bat recipes. Nigerian Field, 40, 46-47.

Francis, C.M., Guillen, A. \& Robinson, M.F. (1999) Order Chiroptera: bats. In Wildlife in Lao PDR. 1999 Status Report (compilers J.W. Duckworth, R.E. Salter \& K. Khounboline), pp. 225-235. IUCN, Wildlife Conservation Society and Centre for Protected Areas and Watershed Management, Vientiane, Lao PDR.

Fujita, M. (1988) Flying foxes and economics. BATS, 6, 4-9.

Fujita, M.S. \& Tuttle, M.D. (1991) Flying foxes (Chiroptera: Pteropodidae): threatened animals of key ecological and economic importance. Conservation Biology, 5, 455-463.

Goodman, S.M. (2006) Hunting of Microchiroptera in southwestern Madagascar. Oryx, 40, 225-228.

Goodman, S.G., Ratrimomanarivo, F.H., Ranivo, J. \& CardifF, S.G. (2008) The hunting of microchiropteran bats in different portions of Madagascar. African Bat Conservation News, $16,4-7$.

Halstead, L.B. (1977) Fruit bats-an example of wildlife management. The Nigerian Field, 52, 50-57.

Heaney, L.R. \& Heideman, P.D. (1987) Philippine fruit bats: endangered and extinct. BATS, 5, 3-5.

Heinrichs, S. (2004) Sulawesi Fruit Bat Conservation and Education Campaign. Unpublished Report for Fauna \& Flora International $100 \%$ Fund, Fauna \& Flora International, Cambridge, UK.

Heinrichs, S. \& Zahnke, K. (1997) The fruit bats of Sulawesi. BATS, 15, 11-15.

Hey mans, J.C. (1994) Utilisation Rationnelle De La Faune SauvageElevage De Petit Gibier. Ministère de l'Agriculture, Pêche et Alimentation, Republique de Guinee Equatoriale.

Hill, J.E. (1991) Bats (Mammalia: Chiroptera) from the Togian Islands, Sulawesi, Indonesia. Bulletin of the American Museum of Natural History, 206, 168-175.

Hladick, C.M., Hladick, A., Linares, O.F., Pagezy, H., Semple, A. \& Hadley, M. (eds) (1993) Tropical Forests, People and Food. Man \& Biosphere Series, Volume 13. UNESCO, Paris, France. 
Hutson, A.M. (1991) Is the Pemba flying fox in danger? Bat News, 21, $4-5$.

Hutson, A.M. (1997) Bats on the Seychelles, Indian Ocean. Bat News, 46, 5 .

Hutson, A.M., Mickleburgh, S.P. \& Racey, P.A. (compilers) (2001) Microchiropteran Bats. Global Status Survey and Conservation Action Plan. IUCN/Species Survival Commission Chiroptera Specialist Group. IUCN, Gland, Switzerland and Cambridge, UK.

IUCN (2008) 2008 IUCN Red List of Threatened Species. IUCN, Gland, Switzerland. Http://iucnwww.redlist.org [accessed 18 December 2008].

Jenkins, R.K.B., Andriafidison, D., Razafimanahaka, J.H., Rabearivelo, A., RaZafindrakoto, N., AndrianandraSANA, R.H. et al. (2007) Not rare, but threatened: the Madagascar flying fox Pteropus rufus in a fragmented landscape. Oryx, 41, 263-270.

JENKINS, R.K.B. \& RACEY, P.A. (2008) Bats as bushmeat in Madagascar. Madagascar Conservation and Development, 3, 22-30.

Johnson, A., Singh, S., Dongdala, M. \& Vongsa, O. (2003) Wildlife Hunting and Use in the Nam Ha Protected Area: Implications for Rural Livelihoods \& Biodiversity Conservation. Wildlife Conservation Society, Vientiane, Lao PDR.

Jones, C. (1972) Comparative ecology of three pteropid bats in Rio Muni, West Africa. Journal of Zoology, London, 167, 353-370.

Juste, J., Fa, J.E., Perezdel Val, J. \& Castroviejo, J. (1995) Market dynamics of bushmeat species in Equatorial Guinea. Journal of Applied Ecology, 32, 454-467.

KrZAnOWSKi, A. (1977) The easternmost occurrence of bats in Polynesia. Fragmenta Theriologica, 22, 271-275.

Kummer, D.M. (1992) Deforestation in the Postwar Philippines. University of Chicago Press, Chicago, USA.

LACERnA, I.D. \& Widmann, P. (1999) Biodiversity utilisation in a Tagbanua community, southern Palawan, Philippines. In Procedures of the International Conference on Applied Tropical Ecology. 8-10 September 1998 (eds F. Goeltenboth, P. Milan \& V.B. Asio), pp. 52-64. Visayas State College of Agriculture, BayBay, Leyte, Philippines.

Lekagul, B. \& McNeely, J.A. (1988) Mammals of Thailand. Darnsutha Press, Bangkok, Thailand.

Leмке, T.O. (1986) Marianas fruit bats near extinction. BATS, $3,1-2$.

Leroy, E.M., Kumulungui, B., Pourrut, X., Rouquet, P., Hassanin, A., YabA, P. et al. (2005) Fruit bats as reservoir of Ebola virus. Nature, 438, 575-576.

Lévi-Strauss, C. (1979) Tristes Tropicoes. Edicoes 90, Lisbon, Portugal.

MacKinnon, J.L., Hawkins, C.E. \& Racey, P.A. (2003) Pteropodidae, Fruit Bats, Fanihy, Angavo. In The Natural History of Madagascar (eds S.M. Goodman \& J.P. Benstead), pp. 1299-1302. University of Chicago Press, Chicago, USA.

Magnus, N. (2001) Bushmeat utilisation in Phu Kheio Wildlife Sanctuary, Northeast Thailand. MSc thesis, University of Alberta, Edmonton, Canada.

Messenger, S.L., Rupprecht, C.E. \& Smith, J.D. (2003) Bats, emerging virus infections and the rabies paradigm. In Bat Ecology (eds T.H. Kunz \& M.B. Fenton), pp. 622-679. University of Chicago Press, Chicago, USA.

Mickleburgh, S.P., Hutson, A.M. \& Racey, P.A. (1992) Old World Fruit Bats. An Action Plan for their Conservation. IUCN/ Species Survival Commission Chiroptera Specialist Group, IUCN, Gland, Switzerland and Cambridge, UK.
Mickleburgh, S.P., Hutson, A.M. \& Racey, P.A. (2002) A review of the global conservation status of bats. Oryx, 36, 18-34.

Mildenstein, T., Stier, S. \& Cariño, A. (2002) Bat Count 2002. Unpublished Report, University of Montana, Missoula, USA and Silliman University, Dumaguete City, Philippines.

Mohd-Azlan, J., Zubaid, A. \& Kunz, T.H. (2001) Distribution, relative abundance, and conservation status of the large flying fox, Pteropus vampyrus, in peninsular Malaysia: a preliminary assessment. Acta Chiropterologica, 3, 149-162.

Monadjem, A., Taylor, P., Cotterill, F.P.D., Kityo, R. \& FAHR, J. (2007) Conservation status of bats in sub-saharan Africa. Bat Research News, 44, 267.

Nicoll, M.E. \& Racey, P.A. (1981) The Seychelles fruit bat Pteropus seychellensis seychellensis. African Journal of Ecology, 19, 361-364.

Nigeria Federal Department of Forestry (1987) Wildife Utilisation and Wildife Values in Nigeria. ISCWM Sub-Saharan Africa. UNESCO, Paris, France.

Noreen, H. \& Claridge, G. (2003) The Wildlife Trade in Laos: The End of the Game. IUCN, Amsterdam, The Netherlands.

O'Connor, T., Riger, P. \& Jenkins, R.K.B. (2006) Endemic fruit bats and conservation education. Journal of the International Association of Zoo Educators, 42, 26-32.

OGilvie, P. \& OGilvie, M. (1964) Observations of a roost of yellow or giant fruit-eating bats, Eidolon helvum. Journal of Mammalogy, 45, 309-310.

Owen, D., Bilton, D., Lonsdale, K. \& Strathdee, S.(compilers) (1987) Proyek Keleawai, A Study of Bats and Invertebrates in an Archipelago's Caves. Final Report of the Oxford University Expedition to the Togian Islands, Sulawesi, Indonesia.

Pearce, J. (1996) Wildlife and Timber Exploitation in Gabon: A Case Study of the Leroy Concession Forest des Abeilles. World Society for the Protection of Animals, London, UK.

Province Sud Nouvelle-Caledonie (2003) Deliberation sur la Modification des Periodes de Chasse aux Roussettes dans la Province Sud. Province Sud Nouvelle Caledonie, Nouvelle Caledonie.

RACEY, P.A. (1979) Two bats in the Seychelles. Oryx, 15, 148-152.

Richardson, P. (1996) Bats in the Solomon Islands. Bat News, $41,4-5$.

Riley, J. (1998) Fruit bat surveys in North Sulawesi. Bat News, 48, 8.

Riley, J. (2002) Mammals on the Sangihe and Talaud Islands, Indonesia, and the impact of hunting and habitat loss. Oryx, 36, 288-296.

Robinson, J. (2008) The endemic Pemba flying fox Pteropus voeltzkowi: population and conservation status. MSc thesis, University of East Anglia, Norwich, UK.

Robinson, J.G. \& Bennett, E. (eds) (2000) Hunting for Sustainability in Tropical Forests. Columbia University Press, New York, USA.

Robinson, M.F. (1993) Khao Luuk Chang Bat Cave, Khao Yai, Thailand: an update. Bat News, 30, 4.

Robinson, M.F. (1994) Observation on the wildlife trade at the daily market in Chiang Khan, northeast Thailand. Natural History Bulletin of the Siamese Society, 42, 117-120.

Robinson, M.F. (1995) The sale of bats as souvenirs in Thailand. Bat News, 38, 5 .

Robinson, M.F. (1998) Chiroptera survey: Xe Piane National Biodiversity Conservation Area, Lao PDR. Natural History Bulletin of the Siamese Society, 46, 155-170.

Seenausen, O. (1991) The Pemba fruit bat Pteropus voeltzkowi-on the edge of extinction? Oryx, 25, 110.

SetZ, E.Z.F. (1991) Animals in the Nambiquara diet: methods of collection and processing. Journal of Ethnobiology, 11, 1-22.

SetZ, E.Z. \& S A Zima, I. (1987) Bats eaten by Nambiquara Indians in Western Brazil. Biotropica, 19, 190. 
Sewall, B.J., Granek, E.F., Carroll, J.B., Feistner, A.T.C., Masfeiled, W., Moutui, M.F.E. et al. (2004) Conservation Action Plan for Livingstone's Flying Fox Pteropus livingstonii. A National Species Action Plan of the Union des Comores, developed by the Comorian NGO Action Comores (antenne Anjouan). Action Comores (antenne Anjouan), Mutsamudu, Anjouan, Union of the Comores.

Shively, G.E. (1997) Poverty, technology, and wildlife hunting in Palawan. Environmental Conservation, 24, 57-63.

Simmons, N. (2005) Order Chiroptera. In Mammal Species of the World. A Taxonomic and Geographic Reference (eds D.E. Wilson \& D.M. Reeder), pp. 312-529. The John Hopkins University Press, Baltimore, USA.

Singaravelan, N., Marimuthu, G. \& Racey, P.A. (in press) Do all fruit bats deserve to be listed as vermin in the Indian Wildlife (Protection) Amended Acts-a critical review. Oryx.

Stebings, B. (1987) Bats, tequila and the King of Siam. BBC Wildlife, January 1987, 4-8.

Steel, E.A. (1994) Study of the Value and Volume of Bushmeat Commerce in Gabon. WWF-Gabon, Libreville, Gabon.

STIER, S.C. (2003) Dietary habits of two threatened co-roosting flying foxes (Megachiroptera), Subic Bay, Philippines. MSc thesis, University of Montana, Missoula, USA.

Struebig, M.J., Harrison, M.E., Cheyne, S.M. \& Limin, S.H. (2007) Intensive hunting of large flying foxes Pteropus vampyrus natunae in Central Kalimantan, Indonesian Borneo. Oryx, 41, 390-393.

Thong, V.D. (2004) A Preliminary Survey of the Bat Fauna of Pu Luong Nature Reserve, Thanh Hoa Province, North-Central Vietnam. Pu Luong-Cuc Phuong Limestone Landscape Conservation Project. Fauna \& Flora International Vietnam Programme, and the Forest Protection Department, Hanoi, Vietnam.

Trewhella, W.J., Reason, P.F., Bullock, R.J., Carroll, J.B., Clark, E.C.M., Davies, J.G. et al. (1995) Conservation of Pteropus livingstonii: catching fruit bats in the Comores. Myotis, 32-33, 297-305.

Trewhella, W.J., Rodriguez-Clark, K.M., Corp, N., Entwistle, A., Garrett, S.R.T., Granek, E. et al. (2005) Environmental education as a component of multidisciplinary conservation programs: lessons from conservation initiatives for critically endangered fruit bats in the Western Indian Ocean. Conservation Biology, 19, 75-85.

Utzurrum, R.C.B., Wiles, G.J., Brooke, A.P. \& Worthington, D.J. (2003) Count methods and population trends in Pacific Island flying foxes. In Monitoring Trends in Bat Populations in the United States and Territories: Problems and Prospects (eds T.J. O'Shea \& M.A. Bogan), pp. 49-61. US Geological Survey Information and Technology Report 2003-003, Washington, DC, USA.
Wheeler, M.E. (1980) The status of the Marianas fruit bat on Saipan, Tinian and Rota. 'Elepaio, 40, 109-113.

Whitten, T. (1992) Wild Indonesia. MIT Press, Cambridge, USA.

Wiles, G.J. (1992) Recent trends in the fruit bat trade on Guam. In Pacific Island Flying Foxes: Proceedings of an International Conservation Conference (eds D.E. Wilson \& G.L. Graham), pp. 53-6o. US Fish and Wildlife Service Biological Report 9o(23). US Department of the Interior, Fish and Wildlife Service, Washington, DC, USA.

Wiles, G.J. (1987) Current research and future management of Marianas fruit bats (Chiroptera: Pteropodidae) on Guam. Australian Mammalogy, 10, 93-95.

Wiles, G.J. (1990) Giving flying foxes a second chance. BATS, $8,3-4$.

Wiles, G.J., Engbring, J. \& Otobed, D. (1997) Abundance, biology and human exploitation in the Palau Islands. Journal of Zoology, London, 241, 203-227.

Wiles, G.J., Lemke, T.O. \& Payne, N.H. (1989) Population estimates of fruit bats (Pteropus mariannus) in the Mariana Islands. Conservation Biology, 3, 66-76.

Wiles, G.J. \& Payne, N.H. (1986) The trade in fruit bats Pteropus spp. on Guam and other Pacific islands. Biological Conservation, $38,143-161$.

WILSON, V.J. \& WILSON, B.L.P. (1991) La chasse traditionnelle et commerciale dans le sud-ouest du Congo. Tauraco Research Report, 4, 279-289.

Wodzicki, K. \& Felten, H. (1980) Fruit bats of the genus Pteropus from the islands Rarotonga and Mangaia, Cook Islands, Pacific Ocean. Senckenbergiana Biologica, 61, 143-151.

\section{Appendices 1-2}

The appendices for this article are available online at http:// journals.cambridge.org

\section{Biographical sketches}

Simon Mickleburgh has been involved in bat conservation at a national and international level since 1984, and co-authored the two IUCN action plans on bats. KERRY WAYLEN is concerned with improving conservation outcomes in developing countries, using both socio-economic and biological knowledge. She is currently carrying out research on the evaluation of community-based conservation projects. PAUL RACEY has worked on the ecology, and reproductive and conservation biology of bats for over 40 years. He is Vice Chairman of Fauna \& Flora International and Co-Chair of IUCN's Chiroptera Specialist Group. 